
\title{
28 Research Suare \\ Effect of CD44 knockdown on the biological characteristics of breast cancer stem cells
}

\section{Zi Lei}

Kunming Medical University

\section{Yang-Li Hu}

People's Liberation Army Joint Logistic Support Force 920th Hospital

\section{Qiang Feng}

People's Liberation Army Joint Logistic Support Force 920th Hospital

\section{Li Wang}

People's Liberation Army Joint Logistic Support Force 920th Hospital

\section{Xin-Yan Pan}

People's Liberation Army Joint Logistic Support Force 920th Hospital

\section{Gui-Yun Li}

People's Liberation Army Joint Logistic Support Force 920th Hospital Ju-Lun Yang ( $\square$ yangjulun@sina.com )

Department of Pathology, Kunming General Hospital

\section{Research article}

Keywords: Breast cancer stem cells; CD44s knockdown; MDA-MB-435

Posted Date: May 26th, 2020

DOI: https://doi.org/10.21203/rs.3.rs-26900/v1

License: (c) (1) This work is licensed under a Creative Commons Attribution 4.0 International License.

Read Full License 


\section{Abstract}

Background: CD44 is an important surface marker of breast cancer stem cells (BCSCs), but it is unclear whether it is involved in the stemness of BCSCs. This has limited the development of new therapeutic strategies for breast cancer. Previous studies have shown that many CD44 variants generated through alternative splicing are involved in the development of breast cancer, but their exact role in BCSCs remains unclear. Therefore, we analyzed the CD44 transcript variants in BCSCs derived from the MDAMB-435 cell line, and aimed to investigate whether CD44s knockdown could affect the biological characteristics of BCSCs.

Methods: $\mathrm{CD} 44^{+} / \mathrm{CD} 24^{-}$cells were isolated among the MDA-MB-435 cells by flow cytometry, and the CD44 transcript variants were detected by RT-PCR in CD44 /CD24 cells. Due to the high expression of CD44 standard splice isoform (CD44s) in CD44 $/$ CD24 cells, CD44s knockdown was generated using small hairpin RNA (shRNA). The effects of CD44s knockdown on the biological characteristics of BCSCs was detected using cell proliferation assay, colony formation assay, cell cycle and apoptosis assay, tumor sphere formation assay, would-healing assay, and Matrigel invasion assay. Tumorigenesis of the $\mathrm{CD} 44^{+} / \mathrm{CD} 24$ cells with CD44s knockdown was investigated in vivo with NOD/SCID mice. The expression of cancer stem cell stemness-related genes, such as Bcl-2, CCNE2, EGFR, MMP7, Muc1, and Myc was also detected by qPCR.

Results: Our results revealed that the mRNA expression of CD44 transcript variants was heterogeneous, and CD44s is highly expressed in BCSCs. CD44s depletion inhibited the proliferation, made cell cycle stay in G0/G1 phase, promoted the apoptosis and necrosis of BCSCs, inhibited the ability of self-renewal and invasion along with the expression of cancer stem cell-related genes in BCSCs. Moreover, CD44s knockdown inhibited the tumorigenesis ability in vivo.

Conclusion: Our findings revealed that CD44s is the predominant isoform expressed in BCSCs, and is an important molecule for maintaining the properties of BCSCs. Targeting CD44s in BCSCs may be a potential new direction for breast cancer treatment.

\section{Background}

The cancer stem cells (CSCs) have the potential of self-renewal and differentiate into multiple types of cancer cells; they are involved in tumorigenesis, metastasis, and resistance to anticancer drugs [1]. An increasing body of evidence has implicated CSCs in a variety of malignancies, thereby suggesting that human cancers are stem cell diseases [2].

Knowledge of CSC-specific biomarkers has facilitated the identification, isolation, and study of CSCs. In 2003 , Al-Hajj et al. found that a minority of breast cancer cells with $\mathrm{CD} 44^{+} / \mathrm{CD} 24^{-/ \text {low }}$ phenotype possessed the ability to form new tumors in NOD/SCID mice. Only100 cells with this phenotype couldform tumors in mice, whiletens of thousands of cells with other phenotypes could not form tumors. 
This population of cells that promotes tumor formation as well as generates tumor cell heterogeneity, contained tumorigenic and non-tumorigenic cells [3]. Dario Ponti isolated and expanded these cells in vitro by mammosphere culture from breast tumor specimens. They obtained $\operatorname{CD} 44^{+} / \mathrm{CD} 24^{-}$cells with the properties of stem/progenitor cells, which were able to form new tumors when little more than $10^{3}$ cells were subjectedinto SCID mice [4]. Clinically, we previously detected $C D 44^{+} / C D 24^{-}$cells in benign hyperplasia of breast, atypical hyperplasia of breast, carcinoma in situ of breast, and invasive breast cancer tissues, which led us to the finding that $\mathrm{CD} 44^{+} / \mathrm{CD} 24^{-}$cells increased with the development of the lesions, and the number of these cells in patients with lymph node metastasis were higher than that in patients without lymph node metastasis. $\mathrm{CD} 44^{+} / \mathrm{CD} 24^{-}$has been widely used as a breast cancer stem cell (BCSC) biomarker [5-8]. However, whether CD44 is a critically functional molecule in maintaining the characteristics of BCSCs remains controversial [9-12]. This has limited the development of new therapeutic strategies for breast cancer. Through alternative spicing, CD44 can generate different isoforms, such as the CD44 standard isoform (CD44s) and CD44 variant isoform (CD44v). Many studies have shown that both CD44s and CD44v are involved in the development of breast cancer [13-17]. However, the exact function and transformational mechanism of each isoform in BCSCs is still unclear.

Therefore, in this study we analyzed the CD44 transcript variants in BCSCs derived from the MDA-MB-435 cell line, and aimed to investigate whether CD44s knockdown could affect the biological characteristics of BCSCs. The results will help shed some light on whether CD44 is just a biomarker of BCSCs or an important molecule that maintains CSC properties, thereby promoting targeted treatment for breast cancer by BCSC-targeting therapy.

\section{Methods}

\section{Cells and cell cultures}

This study received the approved of the Ethics Board of Kunming General Hospital and was also conducted in accordance with the Helsinki Declaration institute of 1975. The MDA-MB-435 human breast cancer cell line was purchased from the American Type Culture Collection (ATCC, Manassas, VA, USA), and were grown in RPMI-1640 Medium supplemented with 10\% heat-inactivated fetal bovine serum (FBS, Biological Industries, Inc., Israel, USA), 100 units $/ \mathrm{mL}$ penicillin and $100 \mu \mathrm{g} / \mathrm{mL}$ streptomycin in humidified conditions with a $5 \% \mathrm{CO}_{2}$ at $37^{\circ} \mathrm{C}$.

\section{RNA preparation and quantitative reverse transcription- polymerase chain reaction (qRT-PCR) analysis}

Total RNA of cells was extracted using the TRIzol reagent (mrcgene, $\mathrm{OH}, \mathrm{USA}$ ) and reverse transcribed to cDNA using the RevertAid ${ }^{\text {TM }}$ H Minus First Strand cDNA Synthesis Kit (Fermentas, Waltham, USA). The $\mathrm{iTaq}^{\mathrm{TM}}$ Universal SYBR Green Supermix kit (Bio-Rad, Hercules, USA) was used to perform PCR 
amplification on the CFX96 ${ }^{\text {TM }}$ Real-Time PCR Detection System. The expression of RNA was normalized to the level of Glyceraldehyde-3-phosphate dehydrogenase (GAPDH) mRNA. Data were analyzed using the Bio-Rad CFX96 Manager software. The sequences for qRT-PCR are listed in Table 1. 
Table 1

Primers used in RT-qPCR

\begin{tabular}{|c|c|c|c|}
\hline Primer NO. & Primer sequence & $\operatorname{Tm}\left({ }^{\circ} \mathrm{C}\right)$ & Product \\
\hline CD44 transcript variants1 F & GAGCAGCACTTCAGGAGGTTA & \multirow[t]{2}{*}{60} & \multirow[t]{2}{*}{$119 \mathrm{bp}$} \\
\hline CD44 transcript variants1 $\mathrm{R}$ & TCATCAAAGTGGTAGCAGGGA & & \\
\hline CD44 transcript variants2 F & CAGGAGGTTACATCTTTTACACC & \multirow[t]{2}{*}{60} & \multirow[t]{2}{*}{$112 \mathrm{bp}$} \\
\hline CD44 transcript variants2 R & TTTGAAGACGTACTGGTAGCAG & & \\
\hline CD44 transcript variants3 F & TTCAGGAGGTTACATCTT & \multirow[t]{2}{*}{60} & \multirow[t]{2}{*}{$78 \mathrm{bp}$} \\
\hline CD44 transcript variants3 $\mathrm{R}$ & ATATTGGTAGCAGGGATT & & \\
\hline CD44 transcript variants4 F & CAGCACTTCAGGAGGTTACATC & \multirow[t]{2}{*}{60} & \multirow[t]{2}{*}{$120 \mathrm{bp}$} \\
\hline CD44 transcript variants4 R & GTGTCTTGGTCTCTGGTAGCA & & \\
\hline CD44 transcript variants5 F & GCTGACCTCTGCAAGGCTTTC & \multirow[t]{2}{*}{60} & \multirow[t]{2}{*}{$99 \mathrm{bp}$} \\
\hline CD44 transcript variants5 $\mathrm{R}$ & АCTGCA ATGCAA ACTGCAGGT & & \\
\hline CD44 transcript variants6 F & TTCAGGAGGTTACATCTT & \multirow[t]{2}{*}{60} & \multirow[t]{2}{*}{$111 \mathrm{bp}$} \\
\hline CD44 transcript variants6 $\mathrm{R}$ & TCATTCCTATTGGTAGCA & & \\
\hline CD44 transcript variants7 F & GCAGCACTTCAGGAGGTTAC & \multirow[t]{2}{*}{60} & \multirow[t]{2}{*}{$119 \mathrm{bp}$} \\
\hline CD44 transcript variants7 R & ATGTGAGTGTCTGGTAGCAGG & & \\
\hline CD44 transcript variants8 F & AGAATTATGGACTCCTTAC & \multirow[t]{2}{*}{60} & \multirow[t]{2}{*}{$187 \mathrm{bp}$} \\
\hline CD44 transcript variants8 $\mathrm{R}$ & CTCAATGGTATAGATAGCA & & \\
\hline GAPDHF & TGACAACAGCCTCAAGAT & \multirow[t]{2}{*}{58} & \multirow[t]{2}{*}{$103 \mathrm{bp}$} \\
\hline GAPDHR & GAGTCCTTCCACGATACC & & \\
\hline CD44F & CAGCACTTCAGGAGGTTACATC & \multirow[t]{2}{*}{58} & \multirow[t]{2}{*}{$120 \mathrm{bp}$} \\
\hline CD44R & GTGTCTTGGTCTCTGGTAGCA & & \\
\hline $\mathrm{Bcl}-2 \mathrm{~F}$ & GAGTGCTGAAGATTGATG & \multirow[t]{2}{*}{58} & \multirow[t]{2}{*}{$110 \mathrm{bp}$} \\
\hline $\mathrm{Bcl}-2 \mathrm{R}$ & TCCTCTGTGATGTTGTATT & & \\
\hline Cyclin E2F & GTTCTTCTACCTCAGTATTCTC & \multirow[t]{2}{*}{58} & \multirow[t]{2}{*}{$114 \mathrm{bp}$} \\
\hline Cyclin E2R & AGCAGCAGTCAGTATTCT & & \\
\hline EGFRF & CTGGTTATGTCCTCATTG & \multirow[t]{2}{*}{58} & \multirow[t]{2}{*}{$120 \mathrm{bp}$} \\
\hline EGFRR & CATAGTTAGATAAGACTGCTA & & \\
\hline MMP7F & CAGTGATGTATCCAACCTAT & 58 & 157 bp \\
\hline
\end{tabular}




\begin{tabular}{|llll|}
\hline Primer NO. & Primer sequence & $\operatorname{Tm}\left({ }^{\circ} \mathrm{C}\right)$ & Product \\
\hline MMP7R & CAATCCAATGAATGAATGAATG & & \\
\hline Muc1F & ACTTCTGCCAACTTGTAG & 58 & $79 \mathrm{bp}$ \\
\hline Muc1R & AAGAACCTGAGTGGAGTG & & \\
MycF & CTCAAGTCATAACAATGCTAA & 58 & $100 \mathrm{bp}$ \\
MycR & AATCAACAGTATCTCCTTCA & & \\
\hline
\end{tabular}

\section{Flow Cytometric Analysis}

To isolate the $\mathrm{CD} 44^{+} / \mathrm{CD} 24^{-}$cells from MDA-MB-435 cells, flow cytometric analysis was performed as previously described [18]. Briefly, $2 \times 10^{6}$ cells were harvested and washed with $1 \mathrm{XPBS}$. PE-conjugated mouse anti-human CD44 monoclonal antibody and fluorescein isothiocyanate (FITC)-conjugated mouse anti-human CD24 monoclonal antibody (all from BD Biosciences, Franklin Lakes, USA) were added to the cells, respectively. After 20 min incubation on ice and in the dark, cells were washed twice with chilled $1 \mathrm{X}$ PBS containing $2 \%$ FBS followed by cell sorting using the flow cytometer (BD FACSVantage SE) [19].

For cell cycle assessment, cells were harvested and washed twice by 1 X PBS, and fixed in $80 \%$ ethanol for 30 min at $4{ }^{\circ} \mathrm{C}$. After washing the cells twice with 1 X PBS, they were suspended in $200 \mu \mathrm{L}$ propidium iodide (PI, $0.1 \mathrm{mg} / \mathrm{mL}, \mathrm{BD}$ Biosciences) and $200 \mu \mathrm{L}$ RNase A (1 mg/mL). After $30 \mathrm{~min}$ incubation on ice and in dark [20], cells were scanned by flow cytometer and data were analyzed using the FlowJo software V7.6.

To detect apoptosis, cells were washed gently with PBS to make a cell suspension followed by centrifugation at $500 \mathrm{~g}$ for $5 \mathrm{~min}$. Using $200 \mu \mathrm{L}$ Binding Buffer, the cells were resuspended at a cell density of $2-5 \times 10^{5}$ cells $/ \mathrm{mL}$. Then, $5 \mu \mathrm{L}$ Annexin V- FITC (BD Biosciences) was added to the $195 \mu \mathrm{L}$ cell suspension followed by incubation at room temperature in dark for $10 \mathrm{~min}$. A total of $190 \mu \mathrm{L}$ binding buffer and $10 \mu \mathrm{L}$ of PI was added to the cells, and incubated in dark at $4{ }^{\circ} \mathrm{C}$ for $30 \mathrm{~min}$. The cell suspension was filtered with 300 mesh nylon mesh. Apoptosis was measured using flow cytometry.

\section{Plasmids And Transduction}

The CD44s-shRNA (Target to CD44 standard isoform transcript variant 4, CD44s, target sequence was GGAAGAAGATAAAGACCATCCTTCAAGAGAGGA

TGGTCTTTATCTTCTTCCTT) and NC-shRNA (Negative Control) were generated by Shanghai GenePharma Co. (GenePharma Co,Ltd, Shanghai, China). The sequences were inserted into the Bbs I and BamHI positions of plasmid pGPU6/GFP/Neo with GFP reporter gene. With this approach, the target sequences were placed between the hU6 promoter and the SV40 polyA signal (Fig. 3). 
Plasmids, pGPU6-CD44s and pGPU6-NC, were transfected into the BCSCs by mixing with Lipofectamine ${ }^{\text {TM }}$ 2000 reagent (Invitrogen, Beijing, China) according to the instructions of the manufacturer. Subsequently, $24 \mathrm{~h}$ after transfection, cells were passaged and were cultured in RPMI-1640 medium containing 10\% FBS and $400 \mu \mathrm{g} / \mathrm{mL} \mathrm{G} 418$. After 10 days, $200 \mu \mathrm{g} / \mathrm{mL}$ G418 was added to the culture in order to maintain the screening pressure. G418-resistant clones were visible approximately 14 days after the selection pressure was applied. After subsequent culture of these clones, we obtained two cell lines with stable expression of CD44s-shRNA (CD44s-shRNA group) and NC-shRNA (NC-shRNA group) [21]. CD44s knockdown was confirmed using qRT-PCR.

\section{Cell Proliferation And Colony Formation Assay}

The CD44s-shRNA, NC-shRNA, and untransfected BCSCs were plated in 24-well plates with $1 \times 10^{4}$ cells per well and incubated at $37^{\circ} \mathrm{C}$. Cell proliferation was assessed on day $1,2,3,4,5,6$, and 7 after transfection by counting the average of three random wells. After observing for seven days, the proliferation curves were drawn. For the colony formation assay, 1000 cells from each group were plated in 6-well plates. After about 4 days, when the cell number of one clone was about 50 , the cells were fixed with formaldehyde and stained using Giemsa staining. The number of clones was determined using images.

\section{Tumor Sphere Formation Assay}

The CD44s-shRNA, NC-shRNA, and untransfected BCSCs were seeded in ultralow attachment plates (Corning, USA) at a density of $3 \times 10^{4}$ viable cells $/ \mathrm{mL}$ in primary culture, respectively. They were then cultured in a sphere culture medium containing serum-free DMEM-F12 (HyClone, Utah, USA), B27 (1:50, Gibco, USA), 10 ng/mL EGF (Peprotech, Rocky Hill, USA), 20 ng/mL bFGF (Peprotech, Rocky Hill, USA), and $5 \mu \mathrm{g} / \mathrm{mL}$ insulin (Sigma, USA). After 5 days, the primary sphere was collected and blown mechanically to a single cell by enzyme digestion (10 $\mathrm{min}$ in $0.05 \%$ trypsin, $0.53 \mathrm{mM}$ EDTA-4Na; Invitrogen, USA). The single-cell were cultured to the next generation. The size and percentage of microspheres were calculated after two weeks[22].

\section{The Matrigel Invasion Assay}

The invasion assay was cultured in a transwell chamber (24-well, $8 \mathrm{mM}$ pore size, Corning). The three groups of cells were plated in the upper chamber with $100 \mu \mathrm{L}$ serum-free RPMI containing $0.2 \%$ BSA ( $1 \times$ $10^{5}$ cells), respectively. A total of $400 \mu \mathrm{L}$ RPMI containing $20 \%$ FBS was placed in the lower chamber as chemoattractant. After $48 \mathrm{~h}$, the cells at the lower surface of the chamber membranes (migrated) were fixed with $90 \%$ ethanol and stained with hematoxylin. The number of migrated cells was counted under the microscope in ten random high power fields (400) per membrane [23]. 


\section{Tumor Growth And Morphologic Analysis In Vivo}

All animals were handled in strict accordance with good animal practices as deemed by the relevant national and local animal welfare bodies, and in accordance with the recommendations in the Guide for the Care and Use of Laboratory Animals of the National Institutes of Health. A total of 12 six-week old female NOD/SCID specific pathogen-free (SPF) mice (Vital River Laboratories, Beijing, China) were fed under SPF conditions, and randomly divided into four groups. A total of $10^{6}, 10^{5}, 10^{4}$, and $10^{3}$ BCSCs were subcutaneously injected into the left back of the four groups of mice, respectively, while each group of mice was subcutaneously injected with BCSCs stably expressing CD44s shRNA into the right back. The subcutaneous tumor formation as well as tumor size and weight of nude mice were observed every two days about 60 days. When the tumor diameters reached $2000 \mathrm{~mm}$, the mice were anaesthetized by intraperitoneal administration of $2 \%$ pentobarbital sodium $(45 \mathrm{mg} / \mathrm{kg})$, and then euthanized by rapid cervical dislocation. The dynamic observation of tumor growth was monitored with calipers using the following formula: Volume $=1 / 2$ (width ${ }^{2} \times$ length) [24]

\section{Histopathology, Immunohistochemistry, And Immunofluorescence}

The cells growing on glass slips and tissue sections of the paraffin-embedded tumor blocks were subjected to hematoxylin and eosin (H\&E) staining [25]. Immunohistochemistry staining was carried out as follows: peroxide was used to block the activity of endogenous peroxidase after PBS flushing followed by addition of CD44 antibody (clone 156-3C11, Newmarkers; 1:200) and CD24 antibody (clone SN3b, Newmarkers; $1: 50$ ) at room temperature, and overnight incubation at $4{ }^{\circ} \mathrm{C}$. Next, biotin-labeled secondary antibody was added followed by DAB staining and hematoxylin restaining. The sections were photographed with microscope scan and analyzed by two pathologists. The Allred immunostaining scoring system was used for semiquantitative evaluation in the three groups of cells [26].A total score was calculated by the sum of the proportion and intensity score,and the staining intensity was scored as 0 (none), 1 (mild), 2 (moderate), or 3 (strong); the proportion of stained cells was scored as 0 (none), 1 (> $0-1 \%), 2$ ( $\geq 1-10 \%), 3$ (>10-33\%), 4 (>33-66\%), and 5 (>66-100\%).

For immunofluorescence, the cells growing on glass slips and the frozen sections of tissues [27] were fixed with acetone for $15 \mathrm{~min}$, followed by three washes with 1X PBS. Then, the tissue sections were incubated with PE-conjugated anti-human CD44 antibody and FITC-conjugated anti-human CD24 antibody (BD Biosciences) [28]. After washing twice with 1X PBS, a drop of glycerol was added on a glass slide, and the slide was analyzed under a fluorescence microscope (Nikon, Tokyo, Japan). The images were acquired using the accompanying software package.

\section{Statistical Analysis}


Each result is expressed as the mean \pm standard deviation. All experiments were performed in triplicates. All statistical analyses were performed using the SPSS software version 11.0. Comparisons among all groups were performed using one-way analysis of variance (ANOVA) and the Student-Newman-Keuls method. Statistical significance is indicated by a $P$ value less than 0.05 .

\section{Results}

\section{Expression of different CD44 isoforms in BCSC subpopulation among MDA-MB-435 cells}

Firstly, we isolated and identified BCSCs in the human breast cancer cell line, MDA-MB-435. The $\mathrm{CD} 44^{+} / \mathrm{CD} 24^{-}$cells were isolated from MDA-MB-435 cells using flow cytometer. The sub-population of CD $44^{+} /$CD $24^{-}$cells in MDA-MB-435 cells was $91.2 \%$ when determined for the first time (Fig. 1A). We continued the culture of $\mathrm{CD} 44^{+} / \mathrm{CD} 24^{-}$cells and detected their numbers again. The population of CD $44^{+} / \mathrm{CD}_{24}{ }^{-}$cells was $100 \%$ when detected the second time (Fig. 1B). The CD44 and CD24 protein expression of $\mathrm{CD} 44^{+} / \mathrm{CD} 24^{-}$cells were confirmed by H\&E staining as well as immunohistochemical analysis and immunofluorescence staining (Fig. 1C). Using immunohistochemistry, the cells were shown to be positive for CD44 protein and negative for CD24 protein. Immunofluorescence analysis revealed cells that showed clear red fluorescent membrane indicating CD44 protein positivity, while being negative for $\mathrm{CD} 24$. According to the previous studies that considered $\mathrm{CD} 44^{+} / \mathrm{CD} 24^{-}$cells as $\mathrm{BCSC}$, we used the $\mathrm{CD} 44^{+} / \mathrm{CD} 24^{-}$cells as BCSCs for the subsequent studies.

The CD44 transcript variants were detected by RT-PCR in BCSCs. The relative expression levels of CD44 transcript variant mRNA in BCSCs, CD44V1, CD44V2, CD44V3, CD44V4, CD44V5, CD44V6, CD44V8, were $0.14 \pm 0.01,0.32 \pm 0.020 .43 \pm 0.01,1.6 \pm 0.01,0.93 \pm 0.04,0.28 \pm 0.02,0,0.32 \pm 0.01$, respectively. The expression of the CD44 transcript variant 4 (standard form, CD44s) mRNA is the highest in BCSCs (Fig. 1D). The data showed that the mRNA expression of CD44 transcript variants was heterogeneous, and CD44s is a suitable siRNA interference target on account of its highest mRNA expression among the CD44 transcript variants.

\section{CD44s depletion inhibits the proliferation, regulates the cell cycle, and promotes the apoptosis and necrosis of BCSCs in vitro}

To determine the proliferation status of CD44s knockdown in BCSCs, CD44s knockdown in BCSCs was achieved using short hairpin RNAs (shRNAs) (Fig. 2A); the stable expression of shRNA targeting CD44 was established in BCSCs (Fig. 2B). The CD44s knockdown efficiency was verified by qRT-PCR and immunohistochemistry both at the mRNA and protein level. The results showed that CD44s knockdown was successfully achieved by CD44shRNA in BCSCs (Fig. 2C, 2D). 
The cell proliferative curve showed that CD44s knockdown significantly reduced BCSC proliferation and the ability of clone formation as compared to that in the negative control (NC-shRNA) and untransfected BCSCs (Fig. 3A, 3B).

In addition, we evaluated the cell cycle by flow cytometry and found that CD44s knockdown resulted in an raising number of cells in the G0/G1-phase and decreased the number of cells in the S-phase (Fig. 3C). Similarly, the apoptosis assay showed that CD44 knockdown can promote the apoptosis and necrosis of BCSCs (Fig. 3D).

These results suggest that CD44s knockdown can induce proliferation of BCSCs by regulating the cell cycle, and promoting apoptosis and necrosis in vitro.

\section{CD44s knockdown inhibits the ability of self-renewal and invasion as well as the expression of cancer stem cell- related genes in BCSCs}

In the tumor sphere formation assay, the number of tumor spheres reflects the quantity of CSCs capable of self-renewal in vitro, and the size of spheres reflects the self-renewal capacity of each spheregenerating cell. The CD44s knockdown inhibited the tumor sphere number and the size of tumor spheres (Fig. 4A). Thus, CD44s knockdown can inhibit the ability of self-renewal.

We next performed the transwell invasion assay to explore the activity of BCSCs with or without CD44s. The data showed that CD44s knockdown could down-regulate BCSC invasion ability (Fig. 4B).

BCSCs are important for maintaining the proliferation and invasion capacities in breast cancer. Hence, we investigated the expression of genes related to proliferation (EGFR and Myc), cell cycle (CCNE2), metastasis (MMP7 and Muc1) and apoptosis (Bcl-2) in BCSCs with or without CD44s. CD44s knockdown was found to significantly reduce the mRNA expression of these genes when compared with the control group in BCSCs (Fig. 4D).

\section{Cd44s Knockdown Inhibits Tumorigenesis Ability In Vivo}

In order to test whether CD44s knockdown would affect tumorigenesis in vivo, xenograft models of human breast cancer were established. In the untransfected BCSC control group, the rate of tumor formation was $100 \%(3 / 3)$, and $66.7 \%(2 / 3)$ when injected with $10^{6}$ cells and $10^{5}$ cell per mice, respectively. However, in the CD44s knockdown BCSC group, the rate of tumor formation was $33.3 \%(1 / 3)$ and $0 \%(0 / 3)$ when injected with $10^{6}$ cells and $10^{5}$ cell per mice, respectively. Tumor-initiating capacity with different numbers of injected cells are shown in Table S1. At 60 days, in the group injected with $10^{6}$ cells, tumors were smaller in size in CD44s-shRNA cells than those in the untransfected BCSCs (Fig. 5A). The tumor growth was slower in the CD44s-shRNA group than that in the control (Fig. 5B). 
In order to observe the morphology of xenografts, we made tissue sections for H\&E staining. It was found that the main difference between the untransfected group and the CD44 knockdown group was the heteromorphism of tumor cells. In the untransfected group, the tumor tissue was arranged in a cord without obvious ductal differentiation with large necrosis in the center, large cell volume, eosinophilic or bright cytoplasm, obvious enlargement and deep staining of nucleus, obvious nucleoli in most cells, strange giant cells in some parts, and pathological mitosis. In the CD44sh RNA group, most cells were of medium size, without large necrosis in the center (Fig. 5C)

To determine the expression of CD44 in vivo, the CD44 protein level was measured by immunofluorescence analysis. It showed that the CD44 protein (red fluorescence) was almost not present in the CD44s-shRNA cells of the tumor tissue, and only the GFP (green) was detected (Fig. 5C).

These findings indicated that CD44s knockdown could inhibit BCSC growth in xenograft tumors.

\section{Discussion}

In the last few decades, numerous cancer therapies have been developed. However, malignancies are still a threat because of relapse as well as resistance to drugs and radiation therapy [1]. The major cause of this resistance is CSCs, which can escape the therapy, leading to relapse and death [29-31]. Recently, targeting CSC surface biomarkers or key molecular signaling pathways of CSCs are emerging as important therapeutic strategies to effectively eradicate cancer [2, 32-34]. Breast cancer cells with $\mathrm{CD} 44^{+} / \mathrm{CD} 24^{-}$phenotype are regarded as BCSCs $[3,31]$. W Li et al. found that high $\mathrm{CD} 44^{+} / \mathrm{CD} 24^{-}$ratio is related to cell proliferation and tumorigenesis in a xenograft tumor model [35]. In primary breast cancer tissues, $\mathrm{CD} 44^{+} / \mathrm{CD} 24^{/ \text {low }}$ cells demonstrated the strongest stemlike properties [36]. We previously found that the expression of $\mathrm{CD} 44^{+} / \mathrm{CD} 24^{-}$cells increased with the development of the lesions and were involved in lymph node metastasis in paraffin embedded breast cancer tissues [37]. These evidences suggest the importance of $\mathrm{CD} 44^{+} / \mathrm{CD} 24^{-}$cancer cells in the progression of breast cancer. The breast cancer cell line, MDA-MB-435, is considered to be the more aggressive cell line, and has the highest proportion of $\mathrm{CD} 44^{+} / \mathrm{CD} 24^{-}$cells $(96.6 \pm 1.2 \%$ ) [38]. Our results also showed that the proportion of $\mathrm{CD} 44^{+} / \mathrm{CD} 24^{-}$cells was $91.2 \%$; therefore, we chose the MDA-MB- 435 cells to isolate the $\mathrm{CD} 44^{+} / \mathrm{CD}^{-} 4^{-}$ cells for studying the properties of BCSCs.

Many studies imply that CD44 is an important biomarker on the surface of BCSCs, and this property was used to isolate BCSCs $[39,40]$. Moreover, some researches showed that CD44 was involved in the tumorigenesis of CSCs in breast cancer $[3,41]$ and other cancers [42-46]. Nevertheless, the results are not conclusive, as some research data suggest that CD44 can maintain the properties of BCSCs. For example, knockdown of CD44 from BCSCs in primary cultures of malignant breast tumors led to differentiation of BCSCs into non-BCSCs with lower tumorigenic potential [47]. Suppression of CD44 by siRNA led to decreased tumorigenicity and cell migration capacity [35]. HA/CD44 signaling promotes protease-dependent invasion of breast cancer cells [48], while other studies showed that CD44 attenuates the features of CSCs. Jose I found that CD44 have a protective role against metastasis during breast 
cancer progression through hyaluronan-CD44 dynamics [11]. Down-regulation of CD44 expression in breast cancer cells, head and neck squamous cell carcinoma cells, and leukemia cells have been shown to make cancer cells more sensitive to anticancer drugs [49-52]. A randomized investigation on breast conservation showed that CD44 is strongly associated with the increased overall survival with 25 years follow-up [53]. These data suggest that CD44 may be functionally critical for CSCs, but based on the dual nature of CD44 in the development of breast cancer, the exact function and mechanism of CD44 needs further exploration.

Since different CD44 splicing variants may display different functions in breast cancer $[12,15,16]$, we previously examined the expression of CD44 splice variants in breast cancer cell lines, MDA-MB-231 and MDA-MB-435, as well as primary breast cancer, and found that CD44 splicing variants were heterogeneously expressed and CD44s expression was higher in breast cancer cell lines and tissues, which correlated with a higher histology grade [54]. In this study, high level of CD44s mRNA was detected in $\mathrm{CD}_{4} 4^{+} / \mathrm{CD} 24^{-}$breast cancer cells. Together with other data [15], we assume that CD44s is the predominant isoform expressed in BCSCs. Therefore, we further investigated the effects of CD44s knockdown on the stemness of BCSCs. The results show that CD44s knockdown significantly inhibits the proliferation of BCSCs. Our findings showed that the proliferation arrest may be through the regulation of cell cycle along with the promotion of apoptosis and necrosis in vitro. Furthermore, CD44s knockdown restrained the invasion, self-renewal, and tumorigenic ability of BCSCs in vivo.

There are plenty of CD44-related pathways, including PI3K/AKT, Rho GTPases, and the Ras-MAPK pathways and so on $[55,56]$. CD44 is reported to interact with EGFR, CCND2, Myc, and Bcl-2, which are up-regulated by Hedgehog signals to promote cellular proliferation, epithelial-to-mesenchymal transition, and bone metastasis $[57,58]$. Up-regulation of secreted-MMP7 through Wnt/ $\beta$-catenin pathway is associated with the loss of tumor suppressor gene, PTEN, in triple negative breast cancer [59]. Mucin 1 (Muc1) is reported to be aberrantly overexpressed in human breast cancer and contributes to the activation of PI3K/AKT, MEK/ERK, Wnt/ $\beta$-catenin, STAT, and NF-KB pathways in breast cancer [60]. Our results also showed that CD44 knockdown can influence the mRNA expression of EGFR, Myc, CCNE2, MMP7, Muc-1, and Bcl-2; however, which among these is involved in CSC-specific signaling and the crosstalk between the complex pathway need to be identified in future studies. The functions of different CD44 splicing variants and the transport mechanism in BCSCs need to be explored.

\section{Conclusions}

In conclusion, our results indicated that CD44s was the predominant isoform expressed in BCSCs, thereby suggesting that $C D 44 s$ is not only a biomarker of BCSCs, but also a breast cancer stemness-related molecule. CD44s is an important functional requirement for maintaining stemness in CSCs. Therefore, interfering with the CD44s and relative oncogenic pathway might provide a novel targeted-therapy based on its capability of BCSC population maintenance.

\section{Abbreviations}


CSCs: cancer stem cells; BCSC: breast cancer stem cell; FBS: fetal bovine serum; GAPDH: Glyceraldehyde3-phosphate dehydrogenase; PI: propidium iodide; FITC: fluorescein isothiocyanate; ANOVA: analysis of variance; shRNAs: short hairpin RNAs.

\section{Declarations}

\section{Ethics approval and consent to participate}

This study received the approved of the Ethics Board of Kunming General Hospital and was also conducted in accordance with the Helsinki Declaration institute of 1975. All animals were handled in strict accordance with good animal practices as deemed by the relevant national and local animal welfare bodies, and in accordance with the recommendations in the Guide for the Care and Use of Laboratory Animals of the National Institutes of Health.

\section{Consent for publication}

Not applicable

\section{Availability of data and materials}

The datasets used and/or analysed during the current study are available from the corresponding author on reasonable request.

\section{Competing interests}

The authors declare that they have no competing interests.

\section{Funding}

This study was funded by grants from the National Natural Science Foundation of China (No. 81460464) and the Major Science and Technology Project of the Yunnan Science and Technology Plan (2018ZF009). The funding body was not directly involved in the design of the study or collection, analysis, and interpretation of data in writing the manuscript.

\section{Authors' contributions}

ZL performed manuscript writing and part of the experiments. YLH carried out the most of the experiments. QF participated in the data organization and manuscript drafting. LW, XYP and LGY engaged in experimental guidance. JYL designed the project. All authors read and approved the final manuscript.

\section{Acknowledgements}

We would like to thank Editage (www.editage.cn) for English language editing. 


\section{References}

1. Jin X, Kim H: Cancer stem cells and differentiation therapy. Tumour biology : the journal of the International Society for Oncodevelopmental Biology and Medicine 2017, 39(10):1010428317729933.

2. Butti R, Gunasekaran VP, Kumar TVS, Banerjee P, Kundu GC: Breast cancer stem cells: Biology and therapeutic implications. Int J Biochem Cell Biol 2019, 107:38-52.

3. Al-Hajj M, Wicha MS, Benito-Hernandez A, Morrison SJ, Clarke MF: Prospective identification of tumorigenic breast cancer cells. Proceedings of the National Academy of Sciences of the United States of America 2003, 100(7):3983-3988.

4. Ponti D, Costa A, Zaffaroni N, Pratesi G, Petrangolini G, Coradini D, Pilotti S, Pierotti MA, Daidone MG: Isolation and in vitro propagation of tumorigenic breast cancer cells with stem/progenitor cell properties. Cancer research 2005, 65(13):5506-5511.

5. Hwang-Verslues WW, Kuo WH, Chang PH, Pan CC, Wang HH, Tsai ST, Jeng YM, Shew JY, Kung JT, Chen $\mathrm{CH}$ et al: Multiple lineages of human breast cancer stem/progenitor cells identified by profiling with stem cell markers. PloS one 2009, 4(12):e8377.

6. Shipitsin M, Campbell LL, Argani P, Weremowicz S, Bloushtain-Qimron N, Yao J, Nikolskaya T, Serebryiskaya T, Beroukhim R, Hu M et al: Molecular definition of breast tumor heterogeneity. Cancer cell 2007, 11(3):259-273.

7. D'Assoro AB, Liu T, Quatraro C, Amato A, Opyrchal M, Leontovich A, Ikeda Y, Ohmine S, Lingle W, Suman $\mathrm{V}$ et al: The mitotic kinase Aurora-a promotes distant metastases by inducing epithelial-tomesenchymal transition in ERalpha(+) breast cancer cells. Oncogene 2014, 33(5):599-610.

8. Dave B, Chang J: Treatment resistance in stem cells and breast cancer. Journal of mammary gland biology and neoplasia 2009, 14(1):79-82.

9. T H, S I, H N: Cancer stem-like cell marker CD44 promotes bone metastases by enhancing tumorigenicity, cell motility, and hyaluronan production. Cancer research 2013, 73(13):4112-4122.

10. McFarlane S CJ, Tibbits P, et al. : CD44 increases the efficiency of distant metastasis of breast cancer. Oncotarget 2015, 60130:11465-11476.

11. Jose I. Lopez TDC, John McDonald, Mark V. Stevens,: CD44 Attenuates Metastatic Invasion during Breast Cancer Progression. Cancer research 2005, 65(15):10.

12. Zhu J, Huang G, Hua X, Li Y, Yan H, Che X, Tian Z, Liufu H, Huang C, Li J et al: CD44s is a crucial ATG7 downstream regulator for stem-like property, invasion, and lung metastasis of human bladder cancer (BC) cells. Oncogene 2019, 38(17):3301-3315.

13. Spadea A, Rios de la Rosa JM, Tirella A, Ashford MB, Williams KJ, Stratford IJ, Tirelli N, Mehibel M: Evaluating the Efficiency of Hyaluronic Acid for Tumor Targeting via CD44. Mol Pharm 2019, 16(6):2481-2493.

14. Hu J, Li G, Zhang P, Zhuang X, Hu G: A CD44v(+) subpopulation of breast cancer stem-like cells with enhanced lung metastasis capacity. Cell Death Dis 2017, 8(3):e2679. 
15. Zhang H, Brown RL, Wei Y, Zhao P, Liu S, Liu X, Deng Y, Hu X, Zhang J, Gao XD et al: CD44 splice isoform switching determines breast cancer stem cell state. Genes \& development 2019, 33(3-4):166179.

16. Zhao P, Xu Y, Wei Y, Qiu Q, Chew T-L, Kang Y, Cheng C: The CD44s splice isoform is a central mediator for invadopodia activity. J Cell Sci 2016, 129(7):1355-1365.

17. Zhang FL, Cao JL, Xie HY, Sun R, Yang LF, Shao ZM, Li DQ: Cancer-Associated MORC2-Mutant M276I Regulates an hnRNPM-Mediated CD44 Splicing Switch to Promote Invasion and Metastasis in TripleNegative Breast Cancer. Cancer research 2018, 78(20):5780-5792.

18. Grimshaw MJ, Cooper L, Papazisis K, Coleman JA, Bohnenkamp HR, Chiapero-Stanke L, TaylorPapadimitriou J, Burchell JM: Mammosphere culture of metastatic breast cancer cells enriches for tumorigenic breast cancer cells. Breast cancer research : BCR 2008, 10(3):R52.

19. Salehi-Lalemarzi H, Shanehbandi D, Shafaghat F, Abbasi-Kenarsari H, Baradaran B, Movassaghpour AA, Kazemi T: Cloning and Stable Expression of cDNA Coding For Platelet Endothelial Cell Adhesion Molecule -1 (PECAM-1, CD31) in NIH-3T3 Cell Line. Advanced pharmaceutical bulletin 2015, 5(2):247253.

20. Gao H, Liu L, Qu ZY, Wei FX, Wang SQ, Chen G, Qin L, Jiang FY, Wang YC, Shang L et al: Antiadenovirus activities of shikonin, a component of Chinese herbal medicine in vitro. Biological \& pharmaceutical bulletin 2011, 34(2):197-202.

21. Zhou Y, Liang QL, Ou WT, Liu QL, Zhang XN, Li ZY, Huang X: Effect of stable transfection with PHD3 on growth and proliferation of HepG2 cells in vitro and in vivo. International journal of clinical and experimental medicine 2014, 7(8):2197-2203.

22. Dontu G, Abdallah WM, Foley JM, Jackson KW, Clarke MF, Kawamura MJ, Wicha MS: In vitro propagation and transcriptional profiling of human mammary stem/progenitor cells. Genes \& development 2003, 17(10):1253-1270.

23. Guo W, Keener AL, Jing Y, Cai L, Ai J, Zhang J, Fu G, Wang Z: FOXA1 modulates EAF2 regulation of AR transcriptional activity, cell proliferation, and migration in prostate cancer cells. The Prostate 2015, 75(9):976-987.

24. Nakahata AM, Suzuki DE, Rodini CO, Fiuza ML, Okamoto OK: RNAi-mediated knockdown of inhibits tumorigenicity of human glioblastoma cells. Oncology letters 2014, 8(4):1487-1491.

25. Wang D, Xu Z, Yu H, Chen X, Feng B, Cui Z, Lin B, Yin Q, Zhang Z, Chen C et al: Treatment of metastatic breast cancer by combination of chemotherapy and photothermal ablation using doxorubicin-loaded DNA wrapped gold nanorods. Biomaterials 2014, 35(29):8374-8384.

26. Allred DC, Harvey JM, Berardo M, Clark GM: Prognostic and predictive factors in breast cancer by immunohistochemical analysis. Modern pathology : an official journal of the United States and Canadian Academy of Pathology, Inc 1998, 11(2):155-168.

27. Fan X, Wang L, Guo Y, Tong H, Li L, Ding J, Huang H: Experimental investigation of the penetration of ultrasound nanobubbles in a gastric cancer xenograft. Nanotechnology 2013, 24(32):325102. 
28. Wang Z, Liu F, Tu W, Chang Y, Yao J, Wu W, Jiang X, He X, Lin J, Song Y: Embryonic liver fodrin involved in hepatic stellate cell activation and formation of regenerative nodule in liver cirrhosis. Journal of cellular and molecular medicine 2012, 16(1):118-128.

29. Albini A, Bruno A, Gallo C, Pajardi G, Noonan DM, Dallaglio K: Cancer stem cells and the tumor microenvironment: interplay in tumor heterogeneity. Connective Tissue Research 2015, 56(5):414425.

30. Lai $Y, Y u X$, Lin $X$, He S: Inhibition of mTOR sensitizes breast cancer stem cells to radiation-induced repression of self-renewal through the regulation of MnSOD and Akt. Int J Mol Med 2016, 37(2):369377.

31. Sun X, Xu C, Xiao G, Meng J, Wang J, Tang SC, Qin S, Du N, Li G, Ren H et al: Breast cancer stem-like cells are sensitized to tamoxifen induction of self-renewal inhibition with enforced Let-7c dependent on Wnt blocking. Int J Mol Med 2018, 41(4):1967-1975.

32. Li Y, Atkinson $\mathrm{K}$, Zhang $\mathrm{T}$ : Combination of chemotherapy and cancer stem cell targeting agents: Preclinical and clinical studies. Cancer letters 2017, 396:103-109.

33. Yang C, Jin K, Tong Y, Cho WC: Therapeutic potential of cancer stem cells. Med Oncol 2015, 32(6):619.

34. Jiang W, Peng J, Zhang Y, Cho WC, Jin K: The implications of cancer stem cells for cancer therapy. International journal of molecular sciences 2012, 13(12):16636-16657.

35. Li W, Ma H, Zhang J, Zhu L, Wang C, Yang Y: Unraveling the roles of CD44/CD24 and ALDH1 as cancer stem cell markers in tumorigenesis and metastasis. Sci Rep 2017, 7(1):13856-13856.

36. Shao J, Fan W, Ma B, Wu Y: Breast cancer stem cells expressing different stem cell markers exhibit distinct biological characteristics. Mol Med Rep 2016, 14(6):4991-4998.

37. LIU Ting-ting WL, CHEN Yue, et al.: The Distribution and Clinicopathologic Significance of

CD44 +/CD24- and CD44-/CD24 + Cells in Benign and Malignant Breast Lesions. China Cancer,2011, Vol20,No8 2011, 20(8):6.

38. Alysha K. Croker DG, Jenny Chu ,Carl Postenka,Benjamin D. Hedley ,David A. Hess,Alison L. Allan: High aldehyde dehydrogenase and expression of cancer stem cell markers selects for breast cancer cells with enhanced malignant and metastatic ability. J Cell Mol Med 2009, 13(8B):17.

39. Barnawi R, Al-Khaldi S, Majed Sleiman G, Sarkar A, Al-Dhfyan A, Al-Mohanna F, Ghebeh H, Al-Alwan M: Fascin Is Critical for the Maintenance of Breast Cancer Stem Cell Pool Predominantly via the Activation of the Notch Self-Renewal Pathway. Stem Cells 2016, 34(12):2799-2813.

40. Deng L, Shang L, Bai S, Chen J, He X, Martin-Trevino R, Chen S, Li X-y, Meng X, Yu B et al: MicroRNA100 Inhibits Self-Renewal of Breast Cancer Stem-like Cells and Breast Tumor Development. Cancer Research 2014, 74(22):6648.

41. Gangopadhyay S, Nandy A, Hor P, Mukhopadhyay A: Breast cancer stem cells: a novel therapeutic target. Clinical breast cancer 2013, 13(1):7-15. 
42. Naor D, Wallach-Dayan SB, Zahalka MA, Sionov RV: Involvement of CD44, a molecule with a thousand faces, in cancer dissemination. Seminars in cancer biology 2008, 18(4):260-267.

43. Pang R, Law WL, Chu AC, Poon JT, Lam CS, Chow AK, Ng L, Cheung LW, Lan XR, Lan HY et al: A subpopulation of CD26+ cancer stem cells with metastatic capacity in human colorectal cancer. Cell stem cell 2010, 6(6):603-615.

44. Aguilar-Gallardo C, Rutledge EC, Martinez-Arroyo AM, Hidalgo JJ, Domingo S, Simon C: Overcoming challenges of ovarian cancer stem cells: novel therapeutic approaches. Stem cell reviews 2012, 8(3):994-1010.

45. Bourguignon LY, Spevak CC, Wong G, Xia W, Gilad E: Hyaluronan-CD44 interaction with protein kinase $\mathrm{C}($ epsilon) promotes oncogenic signaling by the stem cell marker Nanog and the Production of microRNA-21, leading to down-regulation of the tumor suppressor protein PDCD4, anti-apoptosis, and chemotherapy resistance in breast tumor cells. The Journal of biological chemistry 2009, 284(39):26533-26546.

46. Jaworska D, Szliszka E: Targeting Apoptotic Activity Against Prostate Cancer Stem Cells. International journal of molecular sciences 2017, 18(8).

47. Pham PV, Phan NL, Nguyen NT, Truong NH, Duong TT, Le DV, Truong KD, Phan NK: Differentiation of breast cancer stem cells by knockdown of CD44: promising differentiation therapy. Journal of translational medicine 2011, 9:209.

48. Montgomery N, Hill A, McFarlane S, Neisen J, O'Grady A, Conlon S, Jirstrom K, Kay EW, Waugh DJJ: CD44 enhances invasion of basal-like breast cancer cells by upregulating serine protease and collagen-degrading enzymatic expression and activity. Breast cancer research : BCR 2012, 14(3):R84R84.

49. Bourguignon LYW, Earle C, Shiina M: Activation of Matrix Hyaluronan-Mediated CD44 Signaling, Epigenetic Regulation and Chemoresistance in Head and Neck Cancer Stem Cells. International journal of molecular sciences 2017, 18(9).

50. Van Phuc P, Nhan PL, Nhung TH, Tam NT, Hoang NM, Tue VG, Thuy DT, Ngoc PK: Downregulation of CD44 reduces doxorubicin resistance of CD44CD24 breast cancer cells. OncoTargets and therapy 2011, 4:71-78.

51. Wang SJ, Bourguignon LY: Role of hyaluronan-mediated CD44 signaling in head and neck squamous cell carcinoma progression and chemoresistance. The American journal of pathology 2011, 178(3):956-963.

52. Liu YP, Liu CF, Ma DX, Lu F, Zhang JJ, Kong HL: [Effect of CD44 gene silence on multi-drug resistance reversal and biologic activity in K562/A02 cells]. Zhongguo shi yan xue ye xue za zhi 2010, 18(2):335-339.

53. Dan T, Hewitt, S.M., Ohri, N. et al. : CD44 is prognostic for overall survival in the NCI randomized trial on breast conservation with 25 year follow-up. Breast Cancer Res Treat 2014, 143:11.

54. Ju-lun LZCYWLDFGJY: The expression of CD44 splice variants in breast cancer. J Clin Exp Pathol 2012 Jul; 28( 7) 2012 Jul; 28( 7), 28(7):7. 
55. Senbanjo LT, Chellaiah MA: CD44: A Multifunctional Cell Surface Adhesion Receptor Is a Regulator of Progression and Metastasis of Cancer Cells. Front Cell Dev Biol 2017, 5:18.

56. Ouhtit A, Rizeq B, Saleh HA, Rahman MM, Zayed H: Novel CD44-downstream signaling pathways mediating breast tumor invasion. Int J Biol Sci 2018, 14(13):1782-1790.

57. Wobus M, Rangwala R, Sheyn I, Hennigan R, Coila B, Lower EE, Yassin RS, Sherman LS: CD44 associates with EGFR and erbB2 in metastasizing mammary carcinoma cells. App/ Immunohistochem Mol Morphol 2002, 10(1):34-39.

58. Katoh Y, Katoh M: Hedgehog target genes: mechanisms of carcinogenesis induced by aberrant hedgehog signaling activation. Curr Mol Med 2009, 9(7):873-886.

59. Dey N, Young B, Abramovitz M, Bouzyk M, Barwick B, De P, Leyland-Jones B: Differential activation of Wnt-beta-catenin pathway in triple negative breast cancer increases MMP7 in a PTEN dependent manner. PLoS One 2013, 8(10):e77425.

60. Kufe DW: MUC1-C oncoprotein as a target in breast cancer: activation of signaling pathways and therapeutic approaches. Oncogene 2013, 32(9):1073-1081.

\section{Figures}


A
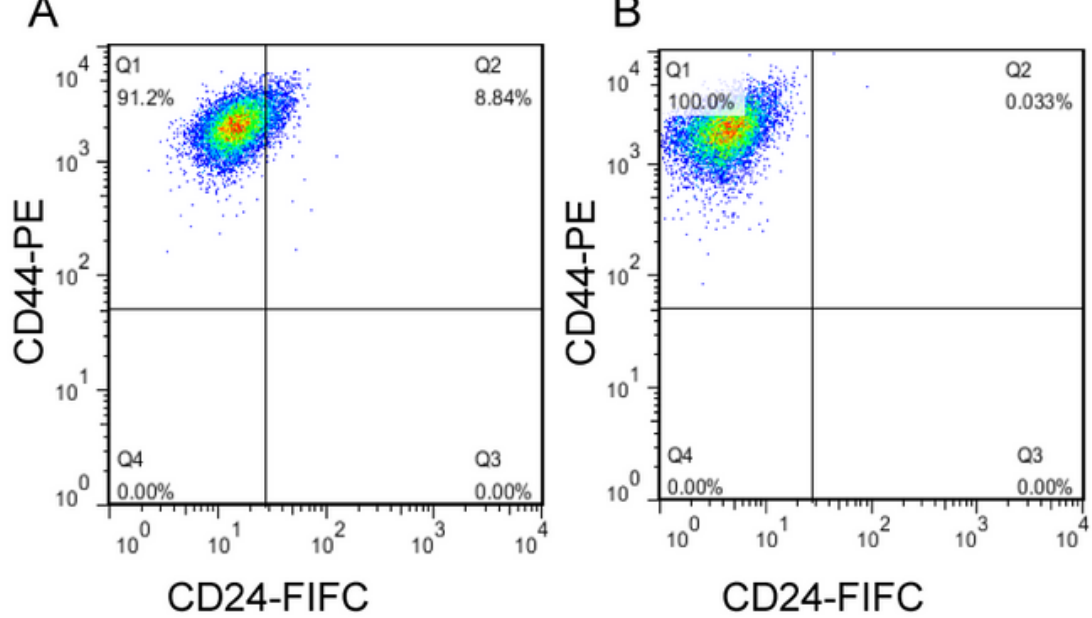

C
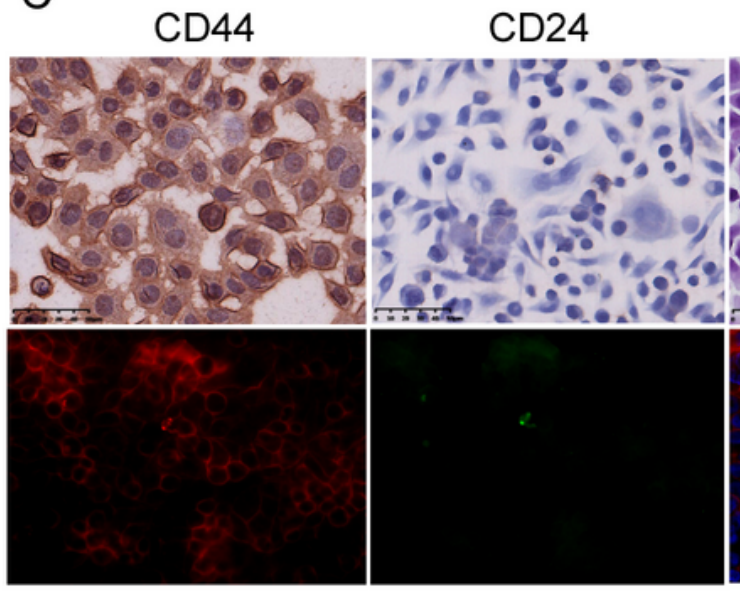

CD44-PE

CD24-FIFC

$\mathrm{HE}$

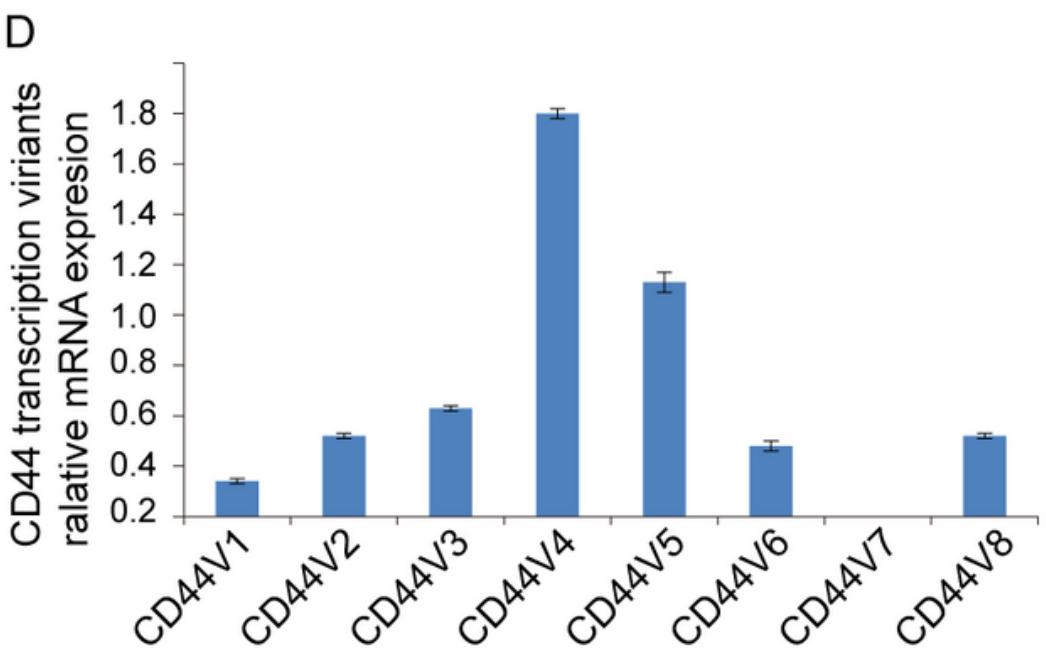

\section{Figure 1}

Isolation of breast cancer stem cells (BCSCs) from human breast cancer cell line, MDA-MB-435, and expression of different CD44 isoforms in BCSC subpopulation of MDA-MB-435 cells. BCSCs were sorted by flow cytometry, the population of CD44+/CD24- cells in MDA-MB-435 FCA was $91.2 \%$ (A). The population of CD44+/CD24- cells in the isolated BCSCs was $100 \%$ (B). The expression and intracellular localization of CD44 and CD24 were determined by hematoxylin and eosin staining (HE) as well as 
immunohistochemistry and immunofluorescence staining, respectively. Immunohistochemistry analysis showed a strong positive expression of CD44 in the cell membrane, while CD24 was negative; immunofluorescence staining displayed CD44 positivity as exhibited by the red fluorescent membrane, while CD24 was negative as expected by the green fluorescent membrane; HE exhibited cell atypia (C). The relative mRNA expression of CD44 transcript variants were tested by RT-PCR. The results showed that CD44 splice variants were heterogeneously expressed in BCSCs, and CD44s expression level was the highest (D). Results are expressed as mean \pm S.D. $n=3$. *Pख0.05; **Pख0.01.

A

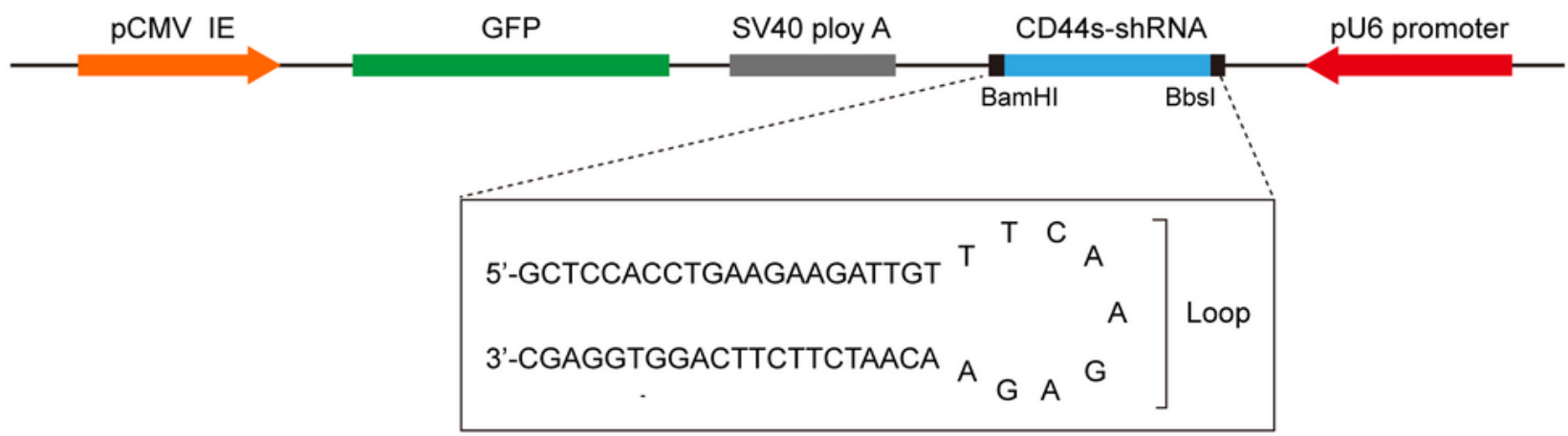

B

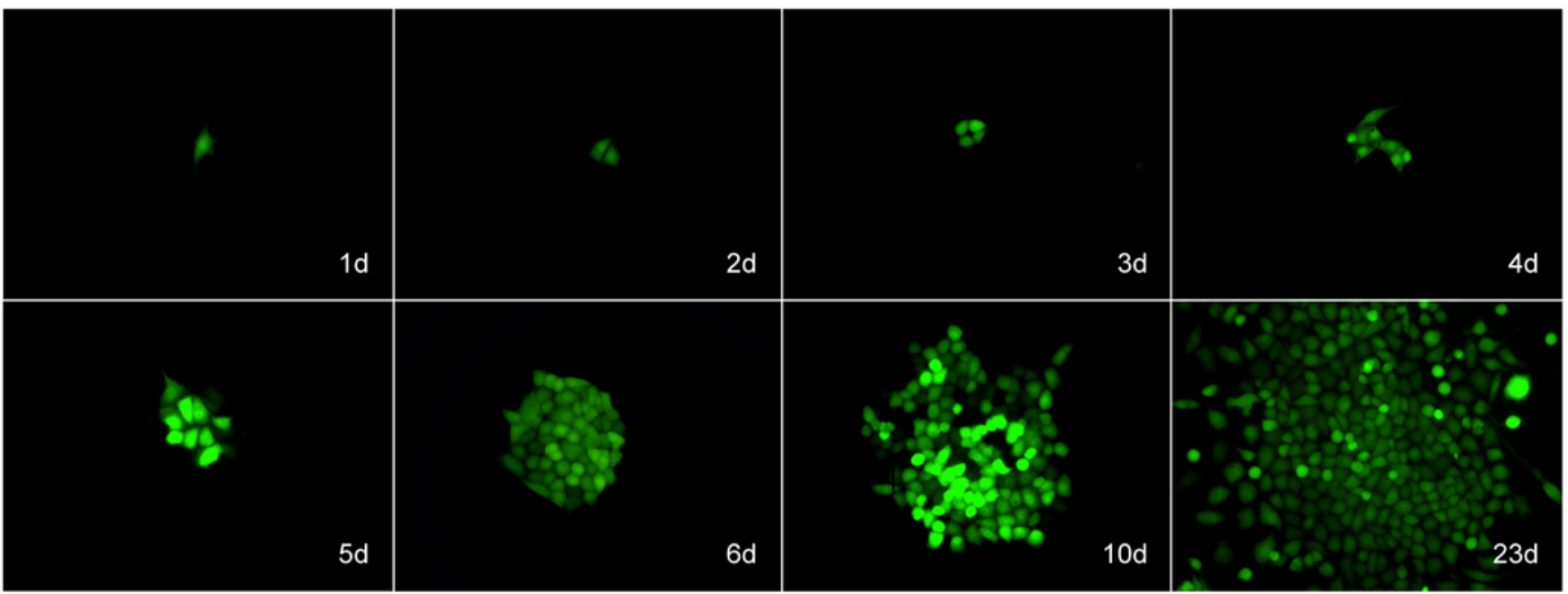

C
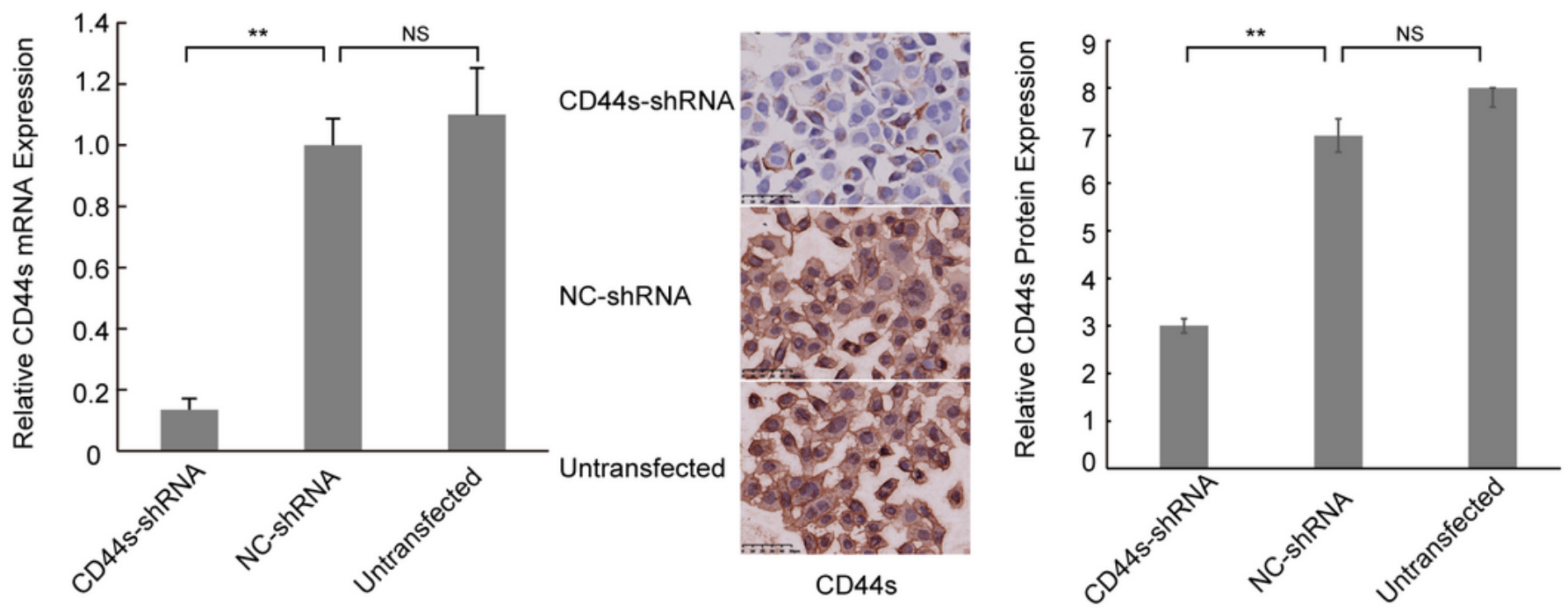
Figure 2

Knockdown of CD44s expression in breast cancer stem cells (BCSCs) CD44s-shRNA was cloned into pGPU6/GFP/Neo between the restriction enzyme site of Bam $\mathrm{HI}$ and Bbs I (A). A single clone formed from a CD44+CD24- cell transfected with CD44s-shRNA (B). CD44s mRNA and protein expression decreased significantly in the BCSCs with CD44s knockdown compared to that in NC-shRNA and untransfected shRNA groups by RT-PCR and immunohistochemistry, respectively. $(C, D)$ Results are expressed as mean \pm S.D. $n=3 .{ }^{*} \mathrm{P} \otimes 0.05 ; * * P \otimes 0.01 ; \mathrm{NS}$, not significant.

A
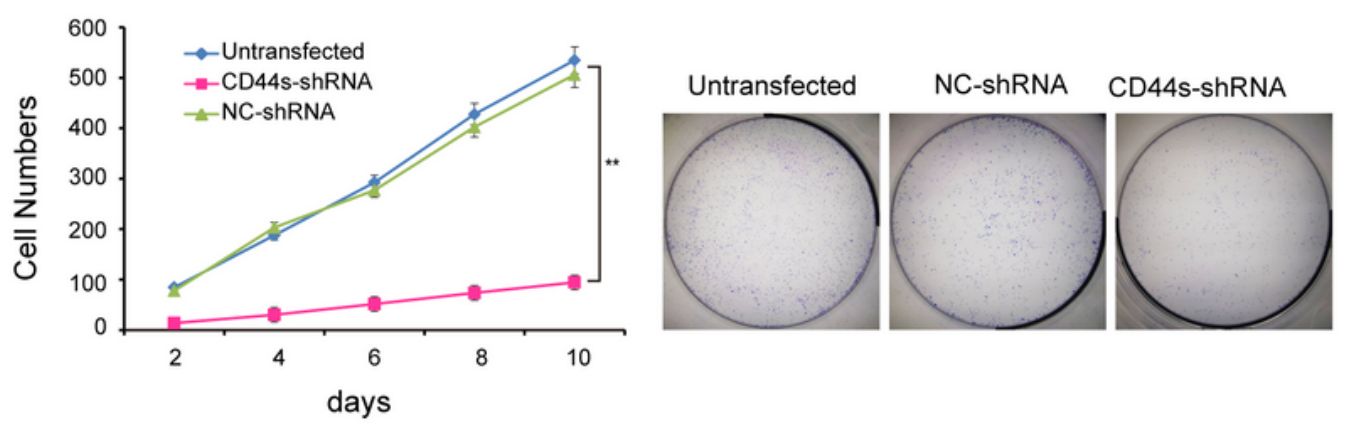

C

Untransfected

NC-shRNA

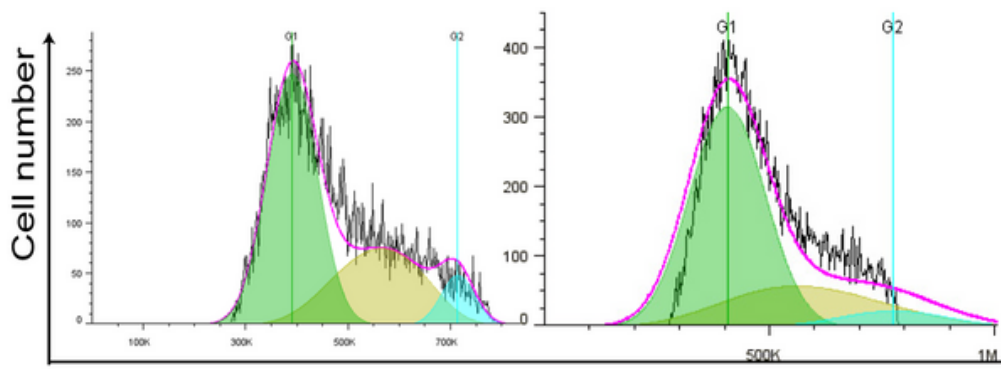

DNA Content

D

Untransfected

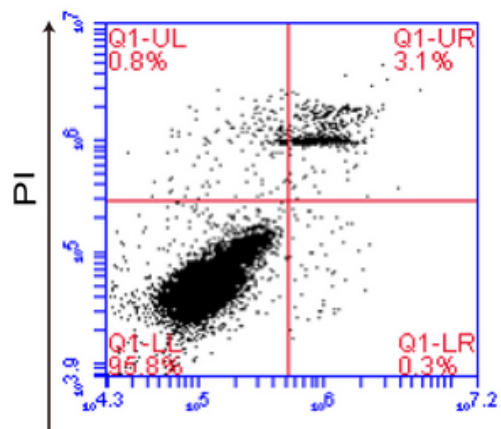

NC-shRNA

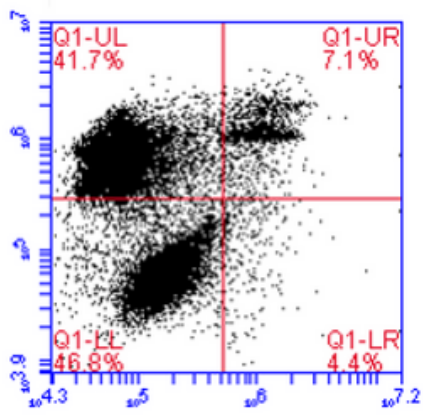

CD44s-shRNA

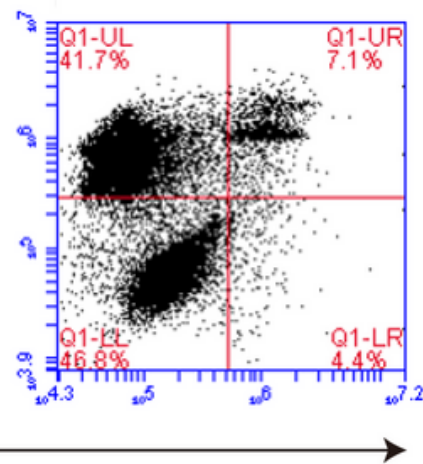

CD44s-shRNA
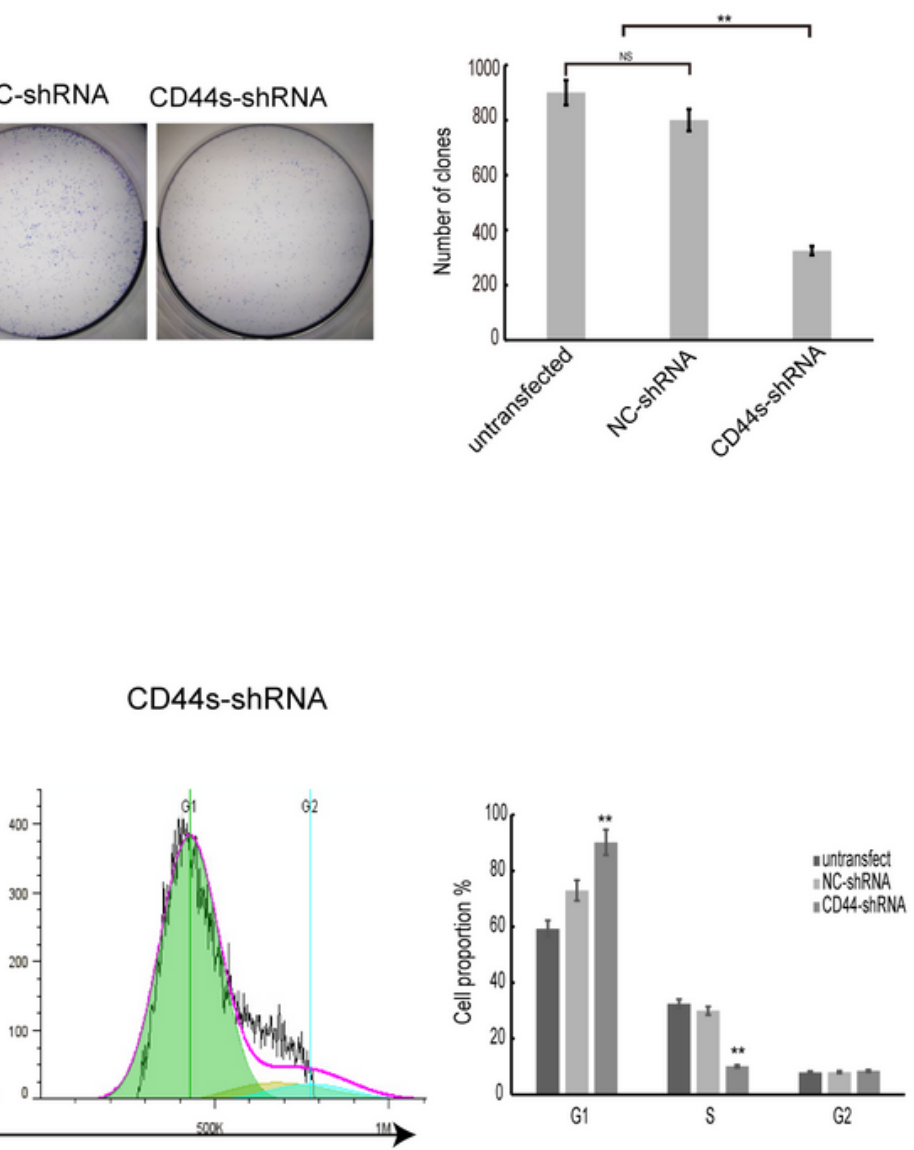

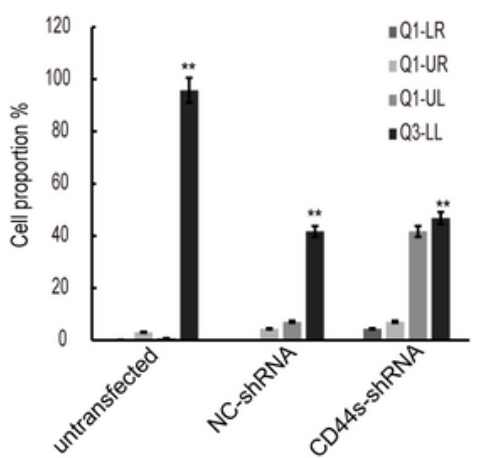




\section{Figure 3}

CD44s knockdown inhibited the proliferation and promoted the apoptosis of breast cancer stem cells (BCSCs) The cell proliferative curve showed that CD44s knockdown inhibited the proliferation of BCSCs by directly counting the cell number at different time points (A). CD44s knockdown is shown to reduce the clonal formation of BCSCs by colony formation assay (B); increased number of cells in the G0/G1-phase and decreased number of cells in the S-phase of cell cycle by flow cytometry (C), apoptosis and necrosis of BCSCs was shown to be promoted by using flow cytometric analysis (D). Q1-LL area: the cells in this area are living cells; Q1-LR area: the cells in this area are early apoptotic cells; Q1-UR area: cells in this area are advanced apoptotic cells; Q1-UL area: the cells in this area are necrotic cells. The typical images and quantitative analysis are shown in the left and right side. Results are expressed as mean \pm S.D. $n=3$. *Pख0.05; **P $₫ 0.01 ; N S$, not significant. 

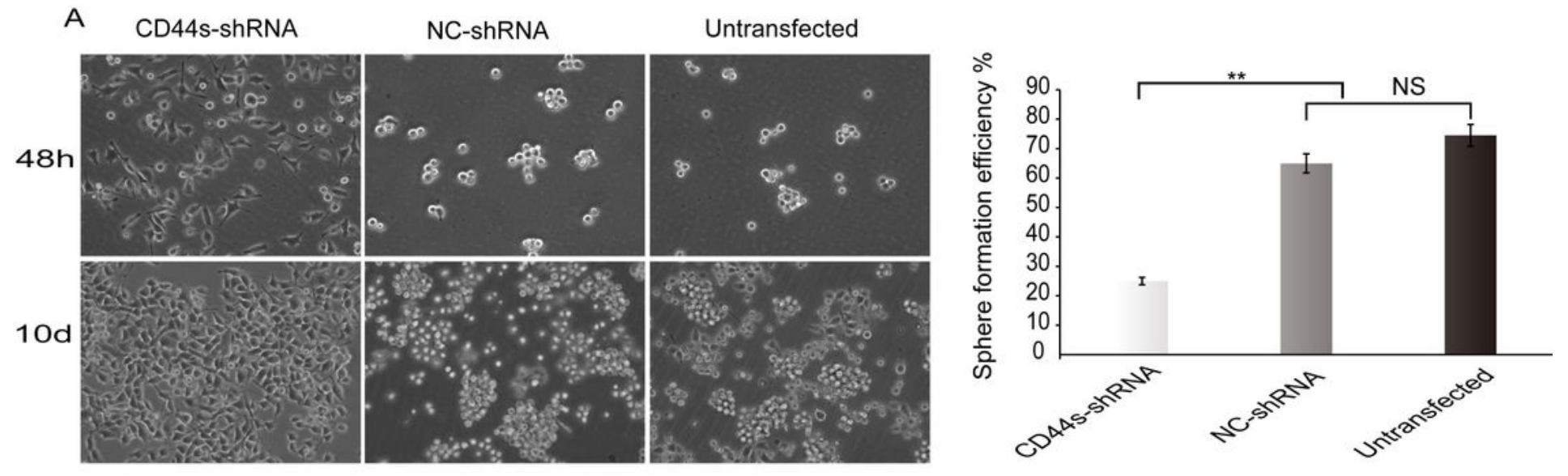

B
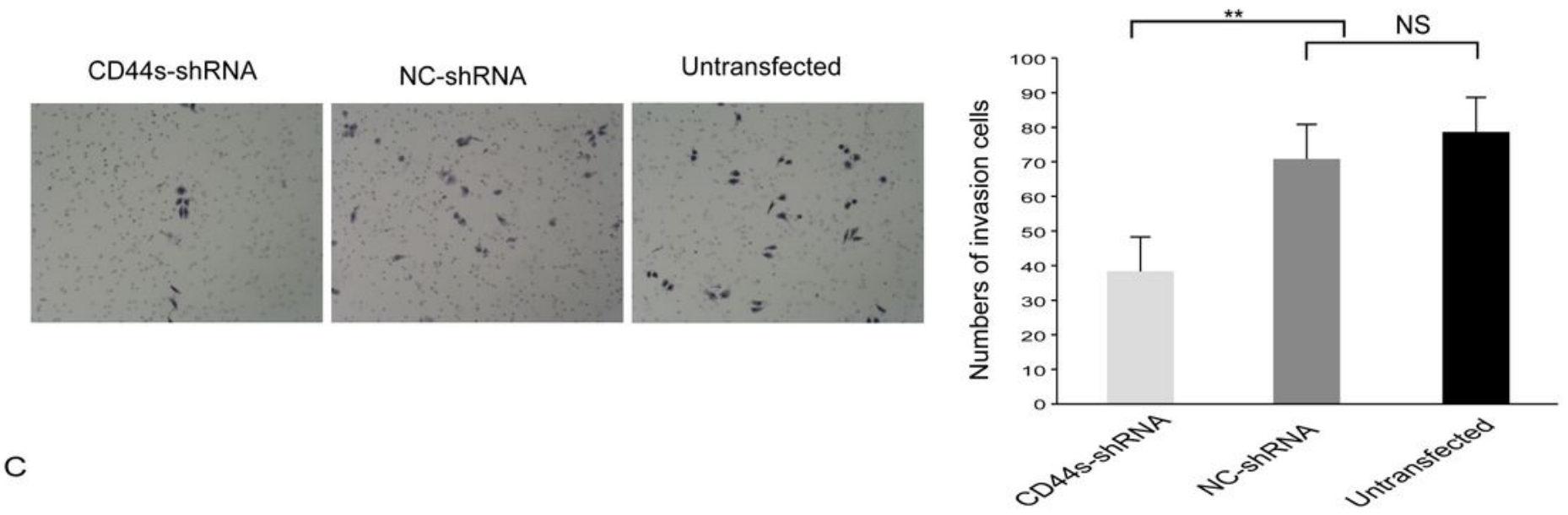

C

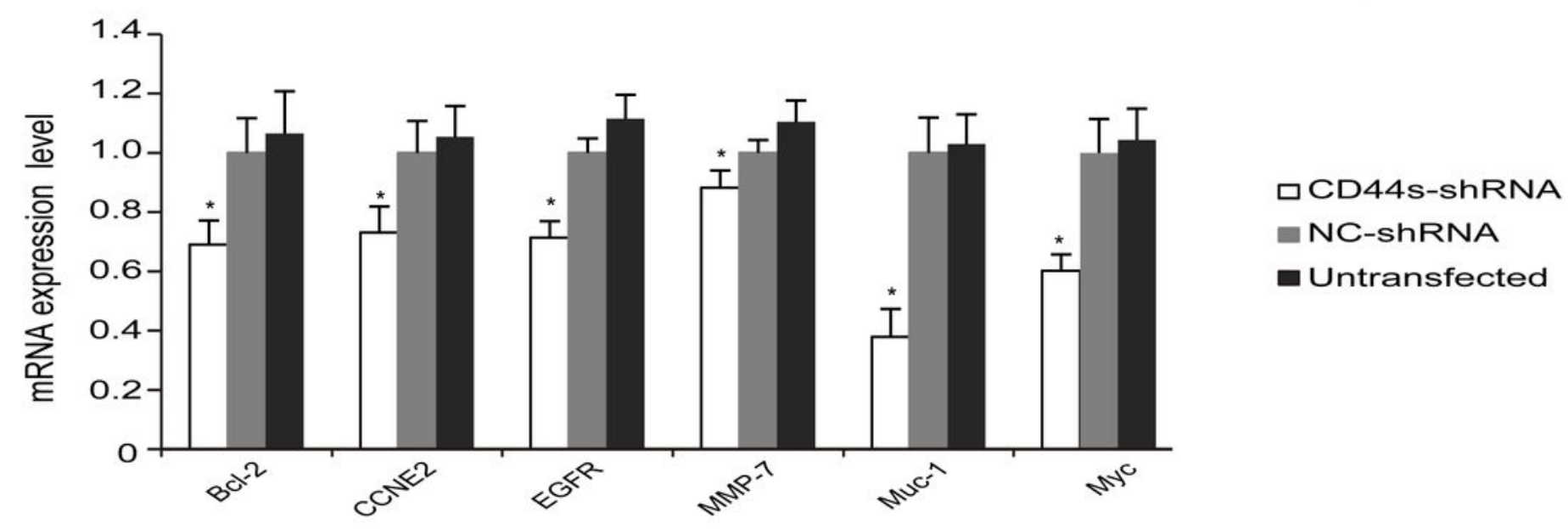

Figure 4

CD44s knockdown inhibited self-renewal capacity and invasion, and down-regulated the expression of cancer stem cell-related genes in breast cancer stem cells (BCSCs) CD44s knockdown is shown to inhibit the sphere formation efficiency of BCSCs using the tumor sphere formation assay (A). Depletion of $\mathrm{CD} 44 \mathrm{~s}$ is shown to inhibit the invasion ability of BCSCs using the transwell invasion assay (C). Cancer stem cell-related genes of BCSCs are shown to be down-regulated with the CD44s knockdown using qRT- 
PCR assay (D). The typical images and quantitative analysis are shown in left and right side (B,C,D). Results are expressed as mean \pm S.D. $n=3$. *P冈0.05; **P冈0.01; NS, not significant.
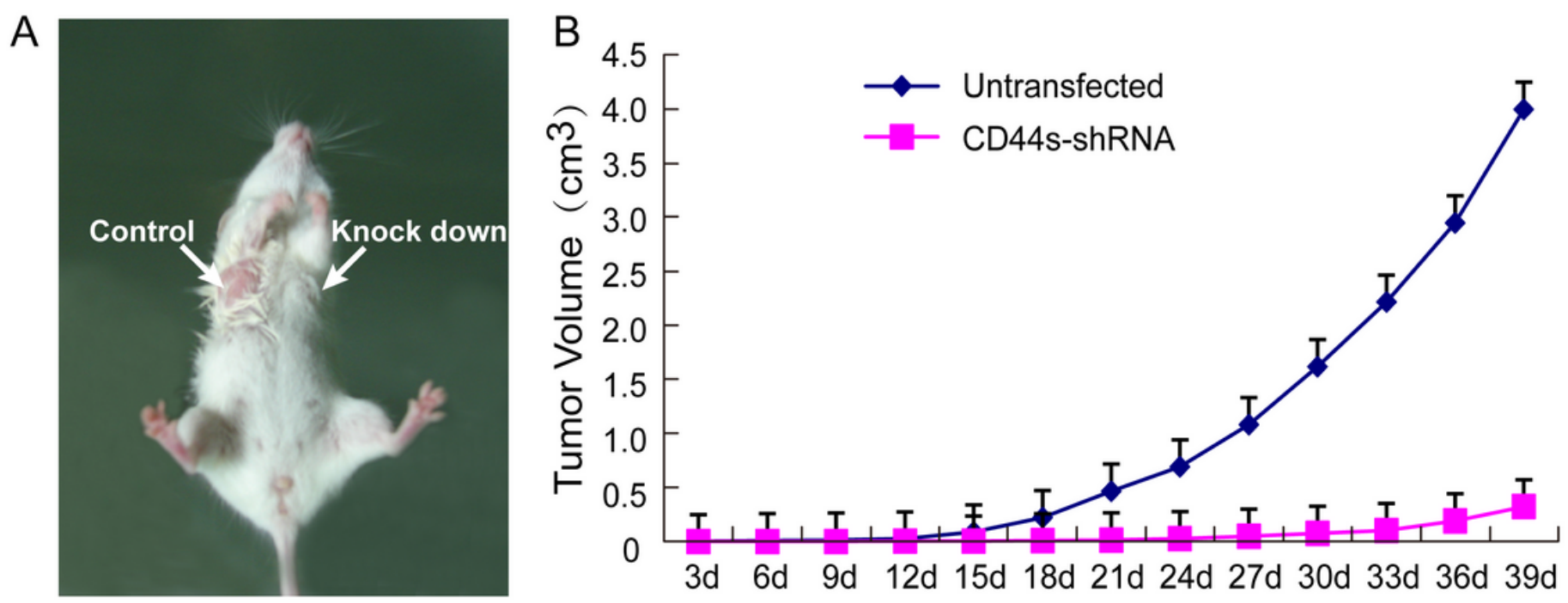

C

HE staining

Immunofluorescence

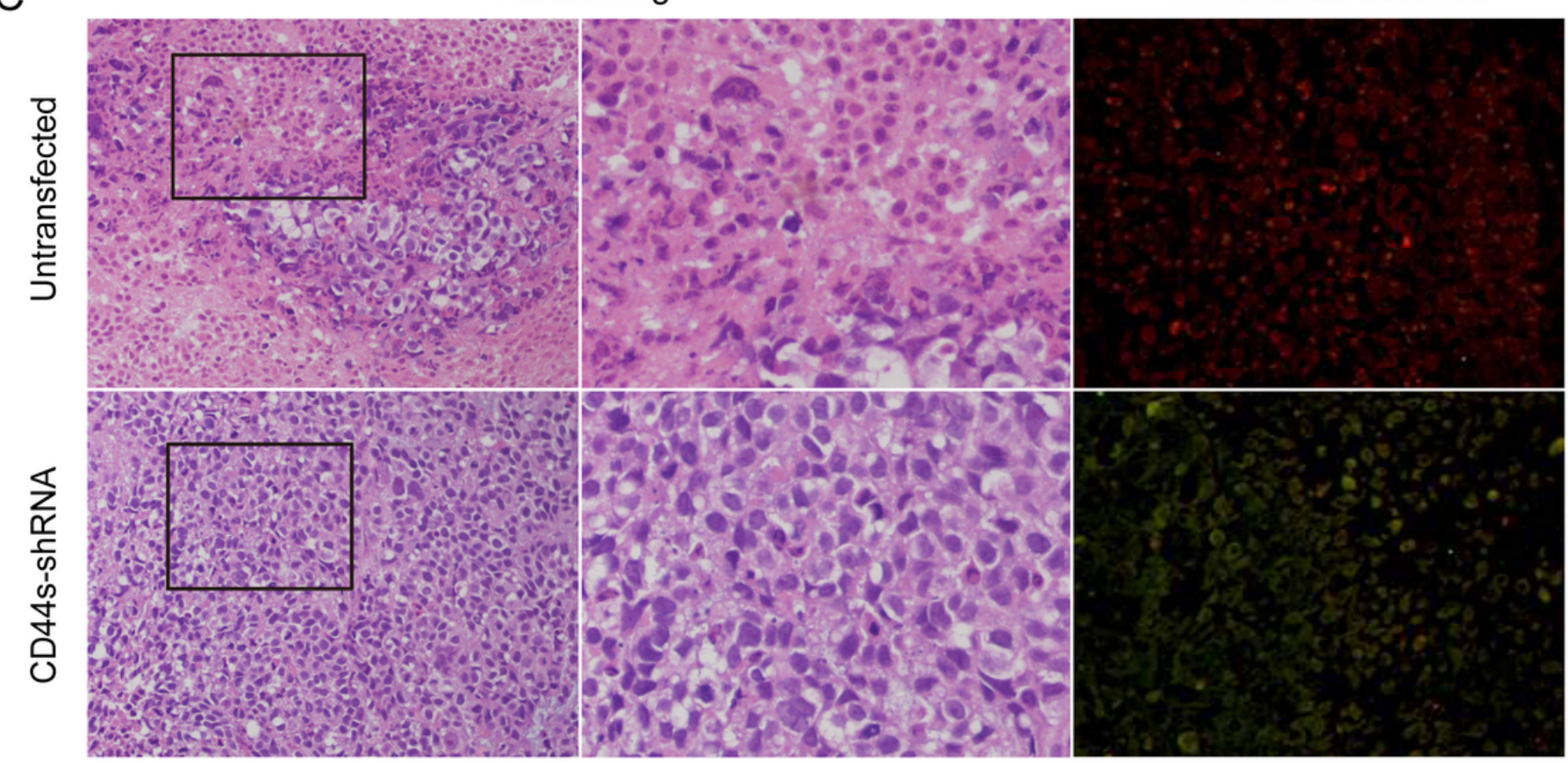

Figure 5

CD44s knockdown inhibited tumorigenesis in vivo The xenograft growth in nude mice with CD44s knockdown cells was significantly inhibited as compared to that in the control group (A). The tumor growth curve showed that the tumor volume of CD44s interference group was significantly smaller than that of the control group (B). The effect of CD44 knockdown on cell morphology were detected by HE stain (C). The results showed that the tumor cells in the untransfected group were large in size, heteromorphic, and necrotic. The tumor cells in the CD44s-shRNA group were smaller in size and less heteromorphic than those in the untransfected group. The expression of CD44 and CD24 in the xenograft 
were detected by immunofluorescence (C, right). The results showed that CD44 was highly expressed (CD44 was red fluorescence), while CD24 was not expressed (CD24 was green fluorescence) in the untransfected group, while the expression of CD44 was weak in the CD44s-shRNA group.

\section{Supplementary Files}

This is a list of supplementary files associated with this preprint. Click to download.

- NC3RsARRIVEGuidelinesChecklistfillable.pdf

- Figuresup1.pdf 